УдК 616.318-089.844

DOI 10.11603/2311-9624.2018.3.9251

CO. В. Ружицыка

Львівський національний медичний університет імені Данила Галицького

(oksanakafedra@gmail.com)

\title{
Перспективи використання жирового тіла щоки для закриття дефектів альвеолярних відростків щелеп
}

Резюме. В сучасній хірургічній стоматологічній практиці лікарі часто стикаються 3 необхідністю закриття дефектів м’яких тканин ротової порожнини. Дослідження останніх років спрямовані на розробку таких методів операції, які б забезпечували санацію запального вогнища, відродження фізіологічних процесів на місці дефекту м'яких тканин, або ж створювали умови для їх відновлення і забезпечували б повноцінну функцію. Мета дослідження - проаналізувати і вивчити літературні дані різних методів застосування жирового тіла щоки (ЖТЩ) для аутотрансплантації при закритті дефектів щелепно-лицевої ділянки порівняно з використанням інших трансплантатів. За останні роки великого поширення набули методи реконструктивної пластики шляхом використання аутотрансплантатів. У літературі $€$ дані про позитивні результати хірургічного закриття дефектів тканин за допомогою аутотрансплантації жирової тканини i, зокрема, жирового тіла щоки. Жирове тіло щоки має власну сполучнотканинну капсулу та добре розвинену судинну сітку, що забезпечує живлення трансплантата і швидке загоєння післяопераційної рани; не потребує попередньої підготовки та адаптації до реципієнтного ложа. Це дозволяє використовувати його у щелепно-лицевій хірургії для закриття дефектів верхньої щелепи, усунення орально-антрального з’єднання, при реконструкції інтраоральних дефектів, таких, як орально-антральна фістула, при втраті кісткової маси нижньої щелепи у ділянках молярів та премолярів, для усунення дефектів при онкологічних патологіях обличчя. Вигідне анатомічне розташування, добре кровопостачання і практично повна відсутність іннервації жирового тіла щоки полегшує завдання хірурга і дає кращі результати операцій. Дослідження доводять процес епітелізації ран на один тиждень після операційного втручання і стабільний клінічний перебіг без ускладнень у віддалені терміни спостереження, що є актуальним у використанні жирового тіла щоки у сучасній щелепно-лицевій хірургії з метою удосконалення існуючих та розробки нових методів аутотрансплантації.

Ключові слова: жирове тіло щоки; дефекти щелепно-лицевої ділянки; методи реконструктивної пластики; остеопластичні матеріали; аутотрансплантація; віддалені терміни спостереження.

\section{(c). В. Ружыцкая}

Львовский национальный медицинский университет имени Данила Галицкого

\section{Перспективы использования жирового тела щеки для закрытия дефектов альвеолярных отростков челюстей}

Резюме. В современной хирургической стоматологической практике врачи часто сталкиваются с необходимостью закрытия дефектов мягких тканей ротовой полости. Исследования последних лет направлены на разработку таких методов операции, которые бы обеспечивали санацию воспалительного очага, возрождение физиологических процессов на месте дефекта мягких тканей, или же создавали условия для их восстановления и обеспечивали бы полноценную функцию. Цель исследования - проанализировать и изучить литературные данные различных методов применения жирового тела щеки (ЖТЩ) для аутотрансплантации при закрытии дефектов челюстно-лицевой области в сравнении с использованием других трансплантатов. За последние годы большое распространение получили методы реконструктивной пластики путем использования аутотрансплантатов. В литературе имеются данные о положительных результатах хирургического закрытия дефектов тканей с помощью аутотрансплантации жировой ткани и, в частности, жирового тела щеки. Жировое тело щеки имеет собственную соединительнотканную капсулу и хорошо развитую сосудистую сетку, обеспечивает питание трансплантата и быстрое заживление послеоперационной раны; не требует предварительной подготовки и адаптации к реципиентному ложе. Это позволяет использовать его в челюстно-лицевой хирургии для закрытия дефектов верхней челюсти, устранения орально-антрального соединения, при реконструкции интраоральных дефектов, таких, как орально-антральная фистула, при потере костной массы нижней челюсти в области моляров и премоляров, для устранения дефектов при он- 


\section{Хірургічна стоматологія}

кологических патологиях лица. Выгодное анатомическое расположение, хорошее кровоснабжение и практически полное отсутствие иннервации жирового тела щеки облегчает задачу хирурга и дает лучшие результаты операций. Исследования доказывают процесс эпителизации ран на одну неделю после операционного вмешательства и стабильное клиническое течение без осложнений в отдаленные сроки наблюдения, что доказывает актуальность использования жирового тела щеки в современной челюстно-лицевой хирургии с целью усовершенствования существующих и разработки новых методов аутотрансплантации.

Ключевые слова: жировое тело щеки; дефекты челюстно-лицевой области; методы реконструктивной пластики; остеопластические материалы; аутотрансплантация; отдаленные сроки наблюдения.

\section{CO. V. Ruzhytska}

Danylo Halytskyi Lviv National Medical University

\section{Prospects of the use of buccal fat pad for closing defects of the alveolar processes of the jaws}

Summary. In modern surgical dental practice, doctors often meet with the need to close the soft tissue defects of the oral cavity. The researches in recent years are aimed to the development of such methods of surgery that would provide sanation of the inflammatory focus, the revival of physiological processes on place of soft tissue defects or create conditions for their recovery and provide a full function. The easy access to buccal fat pad causes interest of regarding its application for the closure of defects. The aim of the study - to analyze and learn the literature data of various methods of application of buccal fat pad for autotransplantation in closing defects of the maxillofacial area in comparison with the use of other transplants. In recent years, a large spread have methods of reconstructive plastic surgery by using autotransplantats. In the literature there are data on the positive results of surgical closure of tissue defects by autotransplantation of adipose tissue and, in particular, the buccal fat pad. The buccal fat pad has its own connective tissue capsule and welldeveloped vascular net, provides nutrition to the transplant and rapid healing of the postoperative wound; does not require prior preparation and adaptation to the recipient's bed. It allows to use it in maxillofacial surgery to close the defects of the upper jaw, elimination of oral-antral connection, in the reconstruction of intraoral defects such as oral-antral fistula, with loss of bone mass of the lower jaw in the area of molars and premolars, to eliminate defects in cancer pathology of the face. Advantageous anatomical position, a good blood circulation and lack of innervation of buccal fat pad facilitates the task of surgeon and gives better results of operations. The studies has shown the process of epithelialization of wounds for 1 week after surgery and a stable clinical course without complications in the long-term observation, which proves the relevance of the use of buccal fat pad in modern maxillofacial surgery with the aim to improve existing and develop new methods of autotransplantation.

Key words: buccal fat pad (Bichat`s fat pad); defects of maxillofacial area; methods of reconstructive plastic surgery; osteoplastic materials; autotransplantation; long-term observation.

У сучасній хірургічній стоматологічній практиці лікарі часто стикаються з необхідністю закриття дефектів м’яких тканин ротової порожнини, які можуть бути як первинними (виникають одразу після операції), так і у вигляді сформованих дефектів, що не загоюються упродовж тривалого проміжку часу після хірургічного втручання [1, 2]. При цьому розмір дефекту м’яких тканин може коливатися від незначного (що не потребує додаткової пластики) до значних розмірів (1-1,5 см і більше).

Така ситуація призводить до деструктивних змін і утворення значних дефектів м'яких тканин альвеолярних відростків щелеп, які можуть бути різної форми та глибини і потребують радикальних хірургічних втручань із закриттям дефекту для відновлення нормальної структури і функції тканин. Для закриття таких дефектів застосовують матеріали біологічного походження і синтетичного виробництва. Це перш за все резорбуючі мембрани та різні остеопластичні матеріали, якими заповнюють кісткові дефекти, а також гомо- й аутотрасплантати [3-6].

При закритті значних дефектів м'яких тканин альвеолярних відростків щелеп хірургу потрібно дотримуватись принципу максимально можливого відновлення опорних тка- 
нин і повного загоєння м'яких тканин. Існує багато способів хірургічного лікування дефектів м'яких тканин альвеолярних відростків щелеп, однак профілактика і хірургічне лікування цих дефектів і на сьогодні залишаються недостатньо вивченими [2, 5, 7].

Метою дослідження було проаналізувати і вивчити літературні дані різних методів застосування жирового тіла щоки (ЖТЩ) для аутотрансплантації при закритті дефектів щелепно-лицевої ділянки порівняно з використанням інших трансплантатів.

Деформація контурів альвеолярних відростків щелеп у результаті дефіциту м'яких тканин супроводжує більшість травматичних ушкоджень, часто зустрічається при інфекційних, запальних захворюваннях, крім цього є результатом різних післяопераційних змін. Дослідження останніх років спрямовані на розробку таких методів операції, які б забезпечували санацію запального вогнища, відродження фізіологічних процесів на місці дефекту м'яких тканин, або ж створювали умови для їх відновлення і забезпечували б повноцінну функцію. Особливо це стосується закриття значних післяопераційних дефектів, які не можливо відновити, використовуючи для пластики місцеві тканини [2, 8].

За останні роки великого поширення набули методи реконструктивної пластики шляхом використання аутотрансплантатів. Безперечно використання аутотканини знижує ризик відторгнення, інфікування, розвитку алергічних реакцій $[9,10]$, що спостерігається при використанні матеріалів біологічного походження і синтетичного виробництва [11-14]. Серед аутотрансплантатів найчастіше використовують клапті на ніжці, взяті з присінка рота, піднебіння, нижньої поверхні язика, а також вільні слизові (з твердого піднебіння, щоки, нижньої поверхні язика) або шкірні (з ділянок живота, стегна, позадувушної чи підключичної ділянки у вигляді тонких - за Thiersch або розщеплених клаптів) трансплантати [15].

У літературі є дані про позитивні результати хірургічного закриття дефектів тканин за допомогою аутотрансплантації жирової тканини i, зокрема, жирового тіла щоки, у прошарках якої є фібробласти, тканинні базофіли, лімфоцити, тонкі колагенові волокна, проходять кровоносні та лімфатичні судини і їх капіляри [9, 16-18]. Жирове тіло щоки, окрім цього, має власну сполучнотканинну капсулу та добре розвинену судинну сітку, що забезпечує живлення трансплантата. Наявність цих структур сприяє регенерації фіброзної тканини, стимулює ріст епітелію слизової оболонки і швидке загоєння післяопераційної рани. А ще жирове тіло щоки не потребує попередньої підготовки та адаптації до реципієнтного ложа [9].

Жирове тіло щоки є важливим утворенням, яке можна використовувати в щелепно-лицевій хірургії для закриття дефектів верхньої щелепи. Через доступність і добре кровопостачання воно може бути використане як трансплантат на ніжці при закритті дефектів м'яких тканин альвеолярних відростків верхньої щелепи та твердого піднебіння. Вигідне анатомічне розташування, добре кровопостачання і практично повна відсутність іннервації полегшують завдання хірурга і дають кращі результати при операції [19].

У 1977 p. P. Egyedi [20] вперше описав метод закриття ороантральних сполучень жировим тілом щоки. Серед його переваг - висока ефективність у відновленні структури і функції, у випадку, коли інші способи не були успішними. 3 того часу жирове тіло щоки стало визнаним варіантом для реконструкції малих i середніх дефектів м'яких тканин у порожнині рота. В 1983 р. А. Neder [21] повідомив про використання жирового тіла щоки в якості вільного трансплантата у 2 пацієнтів із дефектами ротової порожнини, а в 1986 p. H. Tideman [22] описав хірургічну техніку і результати реконструкції дефектів ротової порожнини жировим тілом щоки. $€$ також дані, описані в літературних джерелах (упродовж 2004-2009 рр.), про використання жирового тіла щоки для реконструкції уроджених вад ротової порожнини [23]. Заслуговує уваги дослідження Y. Toshihiro та співавт. (2013) [24], яке було проведено на 23 хворих, де жирове тіло щоки використовували для закриття дефектів слизової оболонки різних ділянок ротової порожнини.

При застосуванні жирового тіла щоки для лікування періімплантитів, досліджено відсутність або слабку інтенсивність болю на 3 добу після операції. Упродовж лікування не спостерігалось ускладнень, виживання і успіх імплантата становив 97,6 \%, а середня гранична втрата кісткової маси через рік після лікування становила $(0,58 \pm 0,27)$ мм [25].

Для успішної кісткової реконструкції дефектів порожнини рота, за даними [26], необхідні перш за все такі фактори, як фізичний захист трансплантата від травми, відсутність грубих 
післяопераційних рубців та добра мікроциркуляція. Дослідникам вдалося досягти усіх умов, використовуючи тільце Біша як мембрану, що підтримує трансплантат кісток.

F. Kablan [27] описує низку досліджень, де жТЩ використовують в комбінації із кістковими замінниками для регенеративного лікування періімплантиту. При цьому автор підкреслює, що донорська ділянка жирового тіла щоки легко доступна у ротовій порожнині, забір трансплантата не супроводжується ускладненнями, а особливо визначає його швидку епітелізацію. Також результати досліджень показали, що жирова тканина може трансформувати тонкий біотип тканин пародонта у товстий, покращуючи тим самим якість та об'єм м'яких тканин у рецепієнтній зоні. Крім цього, автор отримав відмінні функціональні та естетичні результати без повторення періімплантиту.

C. Agarwal [28] успішно застосував жирове тіло щоки при рецесії ясен III-IV класів за Р. Miller, лікування яких практично не приводить до позитивних наслідків. При цьому він досліджував достатній об'єм і структуру тканин трансплантата в реконструктивній ділянці.

За даними [25], тільце Біша успішно застосовували у 57-річної пацієнтки з пухлиною малої слинної залози, розташованої на твердому піднебінні. Автори звертали увагу, що виділення пухлини супроводжувались закриттям дефекту на піднебінні слизовим лоскутом, який через 3 місяці відторгнувся. Повторна операція із застосуванням у якості трансплантата жирового тіла щоки привела до позитивної клінічної динаміки у віддалені терміни спостереження.

Низка бразильських вчених [29] усунення фуркаційних дефектів при комплексному лікуванні запально-деструктивних захворювань тканин пародонта здійснювала за допомогою комбінації аутогенної кістки і жирового тіла щоки в якості мембрани. Клінічно, через 6-12 місяців після лікування, визначали кератизований ясенний край, а рентгенологічно об'єктивізувалось повне відновлення кісткової тканини у ділянці фуркації.

Жирове тіло щоки успішно використовують для усунення орально-антрального з'єднання, яке може виникнути після екстракції молярів та постановки імплантів. Через 15 місяців спостережень у пацієнтів зникли біль, закладеність і виділення з носа [30].

A. Dean та ін. [31] успішно використовували жирове тіло Біша при реконструкції інтра- оральних дефектів, таких, як орально-антральна фістула, при втраті кісткової маси нижньої щелепи у ділянках молярів та премолярів, для усунення дефектів при онкологічних патологіях обличчя. При цьому дослідники визначали процес епітелізації ран на один тиждень після операційного втручання і стабільний клінічний перебіг без ускладнень у віддалені терміни спостереження.

За даними [32], трансплантація жирового тіла Біша на титановій мембрані приводила до позитивних клінічних наслідків при усуненні травми орбітальної ділянки, яка може супроводжуватись вторинним ендофтальмітом. Необхідно зауважити, що така лікувальна тактика приводила до більш швидкої остеоінтеграції за даними комп’ютерної томографії. При використанні цієї техніки відбувається підтримка кісткової мікроархітектури з відповідною мережею кров'яних клітин та власного клітинного вмісту так само, як природа трансплантованого матриксу та його місцеві активатори у вигляді факторів росту, що вивільняються із збагаченої тромбоцитами плазми крові, спричинює формування нової кісткової тканини, як наслідок, механізмів, які включають прямий остеогенез, остеоіндукцію та остеокондукцію.

Вивчаючи макро- і мікроструктуру жирового тіла Біша, не можна обійти увагою антропометричні форми голови та обличчя, від яких суттєво залежить ширина, довжина та об'єм цього утворення.

На величину голови та обличчя впливає не тільки будова лицевого скелета, але і вираження м'яких тканин: м'язів, фасцій, сполучної тканини, підшкірно-жирового шару, шкіри. Індивідуальність обличчя залежить від ступеня його розвитку, від стану здоров'я, расових і конституційних особливостей, віку та статі [33].

Антропометричне дослідження голови полягає у вивченні її розмірів, форми та розмірів обличчя та окремих його частин, а також взаємозв'язку розмірів і форми лицевого відділу черепа та зубоальвеолярних дуг. Вивчаючи голову, використовують три орієнтовані площини за Симоном (1923): серединно-сагітальну, вухо-очноямкову та фронтальну. Ці площини розташовані перпендикулярно одна до одної [34].

У мозковому черепі розрізняють лобову, скроневі, тім'яні та потиличні ділянки, а також основу черепа. Думки про межі обличчя piзні. Одні автори визначають його межі від 
волосистої частини голови до виступальної точки підборіддя; інші - від дотичної, проведеної до верхнього краю брів, до найбільш посторально розташованої точки перенісся. Для того, щоб вивчити обличчя пацієнта і провести на ньому різні вимірювання, необхідно знати розташування антропологічних точок на черепі (краніометричних) і на обличчі (цефалометричних).

Для визначення співвідношень ділянок голови запропоновані індекси, за величиною яких розрізняють типи голови та обличчя. Форму голови визначають відповідно до формули:

широка частина голови/довга частина голови х $100 \%$.

Показники величиною до 75,9 свідчать про доліхоцефалічну форму голови, від 81,0 до 85,1 - мезоцефалічну, 85,5 і більше - брахіоцефалічнy (Williamsta et al. (1995) i Панеро (1979)).

\section{Список літератури}

1. Модина Т. Н. Применение медицинского клея «Сульфакрилат» в стоматологической практике / T. Н. Модина, М. В. Болбат. - Бийск : Издательский дом «Бия», 2014. - 66 с.

2. Цислюк В. П. Лікування хворих з післяопераційними дефектами щелеп : автореф. дис. на здобуття наук. ступеня канд. мед. наук : спец. 14.00.21 «Стоматологія» / В. П. Цислюк. - К., 2001. - 20 с.

3. Беліков О. Б. Ортопедична реабілітація хворих 3 післяопераційними дефектами щелеп і м'яких тканин : автореф. дис. на здобуття наук. ступеня д. мед. наук : спец. 14.00.21 «Стоматологія» / О. Б. Беліков. Полтава, 2006. - 36 с.

4. Вовк Ю. В. Експериментальне вивчення репаративного остеогенезу кісткових дефектів, заповнених кальцій-фосфатним біоматеріалом у поєднанні зі збагаченою тромбоцитами плазмою крові / Ю. В. Вовк, В. Ю. Вовк, О. І. Дельцова // Новини стоматології. - 2009. № 1. - С. 53-63.

5. Хірургічна стоматологія та щелепно-лицева хірургія : підручник у 2-х т. / за ред. В. О. Маланчука. - К. : ЛОГОС, 2011. -320 с.

6. Использование резорбируемых мембран при увеличении альвеолярного отростка методом аутотрансплантации костных блоков / В. А. Маланчук, О. С. Воловар, И. В. Чуганский [и др.] // Стоматологічна імплантологія. Остеоінтеграція : матер. II укр. міжн. конгресу. - К., 2006. - С. 83-84. 7. Тимофеев А. А. Хирургические методы дентальной имплантации / А. А. Тимофеев. - К. : ООО «Червона Рута-Туре», 2007. - 128 с.

8. Вовк Ю. В. Реконструкція післяекстракційних кісткових дефектів зубних лунок за допомогою титанових мембран «Mondeal®»/ Ю. В. Вовк, В. Ю. Вовк // Матер. ювілейної міжнар. наук.-практ. конф. 3 нагоди 50-річчя стомат. $\phi$-ту ЛНМУ ім. Д. Галицького. - Львів, 2008. - С. 68-70.
Форму обличчя за Гарсоном (1980) визначають відповідно до співвідношення:

морфологічна висота обличчя/шири-
на обличчя в ділянці виличних дуг x $100 \%$.

При цьому 78,9 - дуже широке обличчя (гіпереурипрозне); 79,0-83,9 - широке обличчя (еурипрозне); 84,0-87,9 - середне обличчя (мезопрозне); 88,0-92,9 - вузьке обличчя (лептопрозне); 93,0 і більше - дуже вузьке обличчя (гіперлептопрозне) [33, 34].

Отже, аналіз літератури доводить актуальність подальшого дослідження анатомічних особливостей, варіантної анатомії та просторово-часових перетворень топографії жирового тіла Біша. Потреби сучасної щелепнолицевої хірургії вимагають морфологічного підгрунтя для удосконалення існуючих та розробки нових методів аутотрансплантації.

9.Висаитова 3.Ю.Объёмно-контурная пластика лица методом инъекционного введения аутожира : автореф. дисс. на соискание уч. степени канд. мед. наук : спец. 14.00.21 «Стоматология», 14.00.27 «Хирургия» / 3. Ю. Висаитова. - М., 2009. - 26 с.

10. Butterwick K. J. Facial volume restotion with the fat autograft muscle injection technique / K. J. Butterwick, E. A. Lack // Dermatol. Surg. - 2003. - Vol. 29, No.10. P. 1019-1026.

11. Готь I. М. Застосування біоімплантату з плаценти людини в щелепно-лицевій хірургії : метод. рекоменд. / укл. I. М. Готь, Х. Р. Погранична [та ін.]. Львів, 2004. - 25 с.

12. Кобильник I. О. Загальна характеристика біоматеріалів, що використовуються у хірургічній стоматологічній практиці для заповнення післяекстракційних тканинних дефектів. Огляд можливостей перспективних біоматеріалів / I. О. Кобильник // Acta Medica Leopoliencia. - 2001. - T. 7, № 2. - C. 67-71. 13. Применение костнопластического материала как носителя аутогичных стволовых клеток кролика для замещения костного дефекта челюсти / В. И. Куцевляк, В. Ф. Куцевляк, Ю. Е. Микулинский, Е. А. Щегельская // Стоматологічна імплантологія. Остеоінтеграція : матер. II Укр. міжн. конгресу. - К., 2006. - C. 72-82.

14. Knapp T. R. Injectable collagen for soft tissue augmentation / T. R. Knapp, E. N. Kaplan, J. R. Daniels // Plast. Reconstr. Surg. - 1997. - Vol. 60. - P. 398-405.

15. Основи передпротезної хірургічної підготовки порожнини рота / I. М. Готь, Я. Е. Варес, М. М. Угрин [та ін.]. - Львів : ГалДент, 2008. - 52 с.

16. Берштейн Л. М. Эндокринная функция жировой ткани, или как Вас теперь называть, мистер Ж? / Л. М. Берштейн // Природа. - 2005. - № 3. - С. 9-14.

17. Гістологія людини / О. Д. Луцик, А. Й. Іванова, К. С. Кабак [та ін.]. - К. : Книга плюс, 2003. - 280 с.

18. Retrospective study on the treatment outcome 
of surgical closure of oroantral communications / S. H. Visscher, B. van Minnen, R. R. Bos [et al.] // J. Oral. Maxillofac. Surg. - 2011. - Vol. 69, No. 12. - P. 2956-2961. 19. Anatomical structure of the buccal fat pad and Its clinical adaptations / H.-M. Zhang, Y.-P. Yan, K.-M. Qi [et al.] // Plast. Reconstr. Surg. - 2002. - Vol. 109, No. 7. P. 2509-2518.

20. Egyedi P. Utilization of the buccal fat pad for closure of oro-antral and/or oro-nasal communications / P. Egyedi // J. Maxillofac. Surg. - 1977. - No. 5. - P. 241244 .

21. Neder A. Use of buccal fat pad for grafts / A. Neder // Oral Surg. Oral Med. Oral Pathol. - 1983. - Vol. 55. P. 349-350.

22. Tideman $H$. Use of the buccal fat pad as a pedicled graft / H. Tideman, A. Bosanquet, J. Scott // J. Oral Maxillofac. Surg. - 1986. - Vol. 44. - P. 435-440.

23. Six years clinical experience with the dorsally pedicled buccal musculomucosal flap / C. A. Landes, O. Seitz, A. Ballon [et al.] // Ann. Plast. Surg. - 2009. Vol. 62, No. 6. - P. 645-652.

24. Applicability of buccal fat pad grafting for oral reconstruction / Y. Toshihiro, Y. Nariai, Y. Takamura [et al.] // Int. J. Oral Maxillofac. Surg. - 2013. - Vol. 42, No. 5. - P. 604-610.

25. The use of the buccal fat pad for reconstruction of oral defects: review of the literature and report of 15 cases / A. D. Rapidis, C. A. Alexandridis, E. Eleftheriadis [et al.] // J. Oral Maxillofac. Surg. - 2000. - Vol. 58, No. 2. - P. 158-163.

26. Liversedge R. L. Use of the buccal fat pad in maxillary and sinus grafting of the severely atrophic maxilla preparatory to implant reconstruction of the partially or completely edentulous patient / R. L. Liversedge,

\section{References}

1. Modina, T.N., \& Bolbat, M.V. (2014). Primenenie meditsinskogo kleya «Sulfakrilat» v stomatologicheskoy praktike [The application of medical glue "Sulfakrilat» in dental practice]. Biisk: Izdatelskiy dom «Biya» [in Russian].

2. Tsusliuk, V.P. (2001). Likuvannia khvorykh z pisliaoperatsiinymy defektamy shchelep [Treatment of patients with postoperative defects of the jaws]. Extended abstract of Candidate's thesis. Kyiv [in Ukrainian].

3. Belikov, O.B. (2006). Ortopedychna reabilitatsiia khvorykh z pisliaoperatsiinymy defektamy shchelep i miakykh tkanyn [Orthopedic rehabilitation of patients with postoperative defects of the jaws and soft tissues]. Extended abstract of Doctor's thesis. Poltava [in Ukrainian]. 4. Vovk, Yu.V., Vovk, V.Yu. \& Deltsova, O.I. (2009). Eksperymentalne vyvchennia osteohenezu kistkovykh defektiv, zapovnenykh kaltsii-fosfatnym biomaterialom u poiednanni zi zbahachenoiu trombotsytamy plazmoiu krovi [Experimental study of reparative osteogenesis of bone defects filled with calcium-phosphate biomaterial in combination with rich on platelets blood plasma]. Novyny stomatolohii - News of Dentistry, 1, 53-63 [in Ukrainian].

5. Malanchuk, V.O. (Ed.). (2011). Khirurhichna stomatolohiia ta shchelepno-lytseva khirurhiia: pidruchnyk $u$ 2-okh tom. [Surgical dentistry and maxillofacial surgery: textbook in 2 vol.]. Kyiv: LOHOS [in Ukrainian].
K. Wong // Int. J. Oral Maxillofac. Implants. - 2002. Vol. 17, No. 3. - P. 424-428.

27. Kablan F. The use of Buccal fat pad free graft in regenerative treatment of peri-implantitis: A new and predictable technique / F. Kablan // Ann. Maxollofac. Surg. - 2015. - Vol. 5, No. 2. - P. 179-184.

28. Agarwal C. An innovative technique for root coverage using pedicled buccal fat pad / C. Agarwal, G. V. Gayathri, D. S. Mehta // Contemp. Clin. Dent. - 2014. - Vol. 5, No. 3. - P. 386-388.

29. Autogenous Bone Graft, Combined with Buccal Fat Pad as Barrier in Treatment of Class II Furcation Defect: A Case Report / T. M. Deliberador, R. T. Mendes, A. F. Giovanini [et al.] // Bull. Tokyo Dent. Coll. - 2012. - Vol. 53, No. 3. - P. 127-132.

30. Closure of oroantral communications with Bichat`s buccal fat pad. Level of patient satisfaction / R. AlonsoGonzalez, D. Penarrocha-Oltra, A. Aloy-Prosper [et al.] // J. Clin. Exp. Dent. - 2015. - Vol. 7, No. 1. - P. 28-33.

31. The buccal fat pad flap in oral reconstruction / A. Dean, F. Alamillos, A. Garcia-Lopez [et al.] // Head Neck. - 2001. - Vol. 23, No. 5. - P. 383-388.

32. Малаховская В. И. Опыт трансплантации жировой ткани, обогащенной стромально-васкулярной клеточной фракцией для коррекции дефектов челюстно-лицевой области / В. И. Малаховская // Вестник эстетической медицины. - 2013. - № 1. - С. 14-19. 33. Morphological evaluation of head and face shapes in a north-eastern Nigerian population / J. M. Raji, S. H. Garba, A. I. Numan [et al.] // Austr. J. Bas. Appl. Sci. - 2010. -Vol. 4, No. 8. - P. 3338-3341.

34. Spelber G. H. Craniofacial development and growth (craniofacial development) / G. H. Spelber. - London : BC Decker Inc., 2001. - 220 p.

6. Malanchuk, V.A., Volovar, O.S., Tokarskyi, V.F. \& Chuhanskyi, I.V. (2006). Ispolzovanie rezorbiruyemykh membran pri uvelichenii alveolyarnogo otrostka metodom autotransplantatsii kostnykh blokov [The use of resorbable membranes with the increase of the alveolar sprouts of the method of autotransplantation of bone blocks]. Proceedings: II Ukrainskyi mizhnarodnyi conhres "Stomatolohichna implantolohiia.Osteointehratsiia" The Second Ukrainian International Congress "Dental impantology. Osteology". Kyiv [in Russian].

7. Timofeyeva, A.A. (2007). Khirurhicheskiye metody dentalnoy impantatsii [Surgical methods of dental implantation]. Kyiv: OOO «Chervona Ruta-Ture» [in Ukrainian].

8. Vovk, Yu.V. \& Vovk, V.Yu. (2008). Rekonstruktsiia pisliaekstraktsiinykh defektiv zubnykh lanok za dopomohoiu tytanovykh membran «Mondeal@» [Placemarking reconstruction of bone defects of teeth holes with titanium membranes]. Proceedings: yuvileina mizhnarodna naukovo-praktychna konferentsia $Z$ nahody 50-richchia stomat. f-tu LNMU im. D. Halytskoho - Proceedings of the Anniversary International Scientific and Practical Conference dedicated to the 50 years of the Department of Dentistry of Danylo Halytskyi Lviv National Medical University. Lviv [in Ukrainian].

9. Visaytova, Z.Yu. (2009). Obyomno-konturnaya plastika litsa metodom iniektsionnogo vvedeniya autozhira 
[Volume-facial contouring with method of injection of fat inyection requires]. Extended abstract of Candidate's thesis. Moscow [in Russian].

10. Butterwick, K.J. \& Lack, E.A. (2003). Facial volume restotion with the fat autograft muscle injection technique. Dermatologic Surgery, 29, 10, 1019-1026.

11. Hot, I.M., Pohranychna, Kh.R., Siryi, O.M. \& Bihuniak, V.V. (2004). Zastosuvannia bioimplantatu $z$ platsenty liudyny $v$ shchelepno-lytsevii khirurhii: metodychni rekomendatsii [The use of biouplatte from human placenta $t$ in oral and maxillofacial surgery: method. recommendations]. Lviv [in Ukrainian].

12. Kobylnyk, I.O. (2001). Zahalna kharakterystyka biomaterialiv, shcho vykorystovuiutsia u khirurhichnii stomatolohichnii praktytsi dlia zapovnennia pisliaekstraktsiinykh tkanynnykh defektiv. Ohliad mozhlyvostei perspektyvnykh biomaterialiv [General characteristics of the biomaterials used in the surgical dental practice to fill placemarking tissue defects. Overview of the opportunities of prospective biomaterials]. Acta Medica Leopoliencia, 7, 2, 67-71 [in Ukrainian].

13. Kutsevlyak, V.I., Kutsevlyak, V.F., Mikulinskyy, Yu.E. \& Shchehelskaya, E.A. (2006). Primeneniye kostnoplasticheskogo materiala kak nositelya autogichnykh stvolovykh kletok krolika dlya zameshcheniya kostnogo defekta chelusti [The use of osteoplastic material as a carrier of autologous rabbit stem cells to replace bone defect of the jaw]. Proceedings: II Ukrainskyi mizhnarodnyi conhres "Stomatolohichna implantolohiia. Osteointehratsiia» - The Second Ukrainian International Congress "Dental impantology. Osteology». Kyiv [in Russian].

14. Knapp, T.R., Kaplan, E.N. \& Daniels, J.R. (1997). Injectable collagen for soft tissue augmentation. Plastic and Reconstructive Surgery, 60, 398-405.

15. Hot, I.M., Vares, Ya.E., Uhryn, M.M., Shchtuka, O.M. \& Solonko, M.Yu. (2008). Osnovy peredproteznoi khirurhichnoi pidhotovky porozhnyny rota [Basics of preprosthetic surgical preparation of the oral cavity]. Lviv: Haldent [in Ukrainian].

16. Bershtein, L.M. (2005). Endokrinnaya funktsiya zhyrovoy tkani, ili kak vas teper nazyvat, mister Zh? [Endocrine function of adipose tissue, or as You are now called, Mr. A?]. Priroda - Nature, 3, 9-14 [in Russian]. 17. Lutsyk, O.D., Ivanova, A.Y., Kabak, K.S. \& Chaikovskyi, Yu.B. (2003). Histolohiia liudyny [Human Histology]. Kyiv: Knyha plius [in Ukrainian].

18. Visscher, S.H., van Roo n, M.R., Sluiter, W.J., van Minnen, B. \& Bos, R.R. (2011). Retrospective study on the treatment outcome of surgical closure of oroantral communications. Journal of Oral and Maxillofacial Surgery, 69, 12, 2956-2961.

19. Zhang, H.M., Yan, Y.P., Qi, K.M., Wang, J.Q. \& Liu, Z.F. (2002). Anatomical structure of the buccal fat pad and its clinical adaptations. Plastic and Reconstructive Surgery, 109, 7, 2509-2518.

20. Egyedi, P. (1977). Utilization of the buccal fat pad for closure of oro-antral and/or oro-nasal communications. Journal of Maxillofacial Surgery, 5, 241-244.

21. Neder, A. (1983). Use of buccal fat pad for grafts. Oral Surgery. Oral Medicine. Oral Pathology, 55, 349-350.
22. Tideman, H., Bosanquet, A. \& Scott, J. (1986). Use of the buccal fat pad as a pedicled graft. Journal of Oral and Maxillofacial Surgery, 44, 435-440.

23. Landes, C.A., Seitz, O., Ballon, A., Stübinger, S., Robert, S., \& Kovács, A.F. (2009). Six years clinical experience with the dorsally pedicled buccal musculomucosal flap. Annals of Plastic Surgery, 62, 6, 645-652.

24. Toshihiro, Y., Nariai, Y., Takamura, Y., Yoshimura, H., Tobita, T. \& Tyoshino, O. (2013). Applicability of buccal fat pad grafting for oral reconstruction. International Journal of Oral and Maxillofacial Surgery, 42, 5, 604-610. 25. Rapidis, A.D., Alexandridis, C.A., Eleftheriadis, E. \& Angelopoulos, P. (2000). The use of the buccal fat pad for reconstruction of oral defects: review of the literature and report of 15 cases. Journal of Oral and Maxillofacial Surery, 58, 2, 158-163.

26. Liversedge, R.L. \& Wong, K. (2002). Use of the buccal fat pad in maxillary and sinus grafting of the severely atrophic maxilla preparatory to implant reconstruction of the partially or completely edentulous patient. The International Journal of Oral \& Maxillofacial Implants, 17, 3, 424-428.

27. Kablan, F. (2015). The use of buccal fat pad free graft in regenerative treatment of peri-implantitis: A new and predictable technique. Annals of Maxillofacial Surgery, $5,2,179-184$.

28. Agarwal, C., Gayathri, G.V., \& Mehta, D.S. (2014). An innovative technique for root coverage using pedicled buccal fat pad. Contemporary Clinical Dentistry, 5, 3, 386388.

29. Deliberador, T.M., Mendes, R.T., Storrer, C.L., Giovanini, A.F., Zielak, J.C., \& Lopes, T.R. (2012). Autogenous bone graft combined with buccal fat pad as barrier in treatment of Class II furcation defect: a case report. The Bulletin of Tokyo Dental College, 53, 3, 127-132. 30. Alonso-González, R., Peñarrocha-Diago, M., Peñarrocha-Oltra, D., Aloy-Prósper, A., CamachoAlonso, F. \& Peñarrocha-Diago, M. (2015). Closure of oroantral communications with Bichat's buccal fat pad. Level of patient satisfaction. Journal of Clinical and Experimental Dentistry, 7, 1, 28-33.

31. Dean, A., Alamillos, F., García-López, A., Sánchez, J. \& Peñalba, M. (2001). The buccal fat pad flap in oral reconstruction. Head \& Neck, 23, 5, 383-388.

32. Malakhovskaya, V.I. (2013). Opyt transplantatsii zhyrovoy tkani, oboyashchennoy stromalnovaskulyarnoy kletochnoy fraktsiyey dlya korrektsii defektov chelustno-litsevoy oblasti [The experience of transplantation of adipose tissue enriched with stromal vascular cellular fraction for the correction of defects of the maxillofacial area]. Vestnik esteticheskoy meditsinyBulletin of Aesthetic Medicine, 1, 14-19 [in Russian].

33. Raji, J.M., Garba, S.H., Numan, A.I., Waziri, M.A. \& Maina, M.B. (2010). Morphological evaluation of head and face shapes in a north-eastern Nigerian population. Australian Journal of Basic and Applied Sciences, 4, 8, 3338-3341.

34. Spelber, G.H. (2001). Craniofacial development and growth (Craniofacial development). London: BC Decker Inc.

Отримано 19.06.18 